\title{
An Empirical Study of Institutional Investor and Enterprise Innovation
}

\author{
Cheng Min \\ SHU-UTS SILC Business School, Shanghai University, \\ Shanghai, P.R.China
}

Doi: 10.19044/esj.2018.v14n1p227 URL:http://dx.doi.org/10.19044/esj.2018.v14n1p227

\begin{abstract}
Innovation is the driving force of social and economic development, and a decisive factor in enhancing national competitiveness. In recent years, more and more countries have taken innovation to a strategic height. Chinese institutional investors have an increasing share of the overall ownership and make a remarkable improvement in the market position. Based on an increasingly significant role in the capital market, they actively intervene in the management of the enterprise, focusing on long-term improvement of corporate performance. Correspondingly,

Institutional investors can also affect the level of technological innovation by participating in corporate governance. This study analyzes the mechanism of institutional investment affecting the technological innovation of enterprises, and takes an empirical test of institutional investors on the impact of technological innovation. The results show that the overall ownership of institutional investors has a significant positive impact on corporate R\&D expenditure. This paper proposes that the future policies should still be oriented toward the development and support of institutional investors, and give further play to their efforts to promote technological innovation of enterprises.
\end{abstract}

Keywords: Institutional Investor, R \& D Expenditure, Enterprise Innovation

\section{Introduction}

The development momentum of new scientific and technological revolution is becoming more and more rapid. The world economic pattern has brought about new changes. Intellectual capital has been replacing labor capital and dominates the era of knowledge-based economy. Strengthening innovation and stimulating economic growth through innovation have become the consensus of most countries in the world. In 2016, Chinese State Council issued the 'Outline of National Innovation-Driven Development Strategy', 
which further promoted the development of innovation-driven development to the priority of the country and set a goal of entering into an innovation-oriented country by 2020 , becoming one of the top innovators in the world by 2030 , and building a world science and technology innovation country by 2050 .

These three step goals are strategically aimed to make China become a leader in a number of important fields and a participant in the formulation of important rules by further enhancing independent innovation. As strong support for economic and social development, technological innovation activities are a kind of special investment behavior of enterprises. They have the characteristics of 'high input, high risk, long investment recovery cycle and high expected return'.

In 1912, innovative theories proposed by J.A.Joseph firstly attribute the driving force of economic development to innovation. Since then, the theoretical research on technological innovation has never stopped. With the third scientific and technological revolution, a large number of high-tech industries have mushroomed, triggering the transformation of a wide range of industrial structures and bringing significant economic benefits, which have had a tremendous impact on social life and economic development.

The academic community has started to pay attention to the company, dynamic market entity, constantly studying and defining its technological innovation behavior and inherent mechanism of action. Researchers constantly verify innovation theories through empirical analysis. Many factors affect the technological innovation of enterprises including corporate internal and external governance mechanisms is a very important factor. Chinese research in related fields started later. At present, the research mainly focuses on the influence of internal governance factors such as ownership structure and management incentives on the technological innovation of the company. In western countries, institutional investors have always been the research focus in corporate governance. In recent years, the development of institutional investors in China is growing rapidly, and the impact on corporate governance has also become increasingly prominent. A lot of literature research shows that institutional investors in China have been involved in the internal and external governance of listed companies and have the effect of influencing the company's investment decision-making. Therefore, logically speaking, there is a certain intrinsic relationship between institutional investors and enterprises' technological innovation behavior. Most of Chinese research focuses on holding preference and investment strategies of institutional investors.

At present, most Chinese researches on the relation between enterprises' technological innovation and institutional investors are mostly in single industry. In the moment when institutional investors in China continue to grow, it is worthwhile for institutional investors to be able to restrain short- 
sighted management and promote technological innovation in order to obtain a stable return on capital markets. Now that the R \& D activities of enterprises are so important to the innovative development of enterprises, this study continues to explore the impact of institutional investors on R\&D expenditure. This paper conducts a theoretical and empirical study on the relationship between institutional investors and business innovation in China. The research in this paper can give advice to the government in guiding the healthy development of institutional investors in real economic life and truly play important role of capital market.

\section{Literature review}

The research on institutional investors and business innovation mostly focuses on the $\mathrm{R} \& \mathrm{D}$ investment of listed companies and also forms a relatively complete system. To sum up, there are mainly two kinds of views as follows: (1) Institutional investors are pro-active, which will strengthen the supervision over the R \& D investment behavior of enterprises, restrain the managers from reducing $\mathrm{R} \& \mathrm{D}$ investment to carry out earnings management, ensure Long-term interests in management decision, so as to promote the improvement of enterprise's technological innovation level; (2) Institutional investors are negatively short-sighted, focusing only on short-term interests. Institutional investors will inhibit $\mathrm{R} \& \mathrm{D}$ investment behavior of the management, and negatively impact technological innovation of enterprises.

Research literature on the positive role of institutional investors in enterprise R \& D investment are as follows. Holderness \& Sheehan (1988) argued that the high proportion of shares held by institutional investors leads to higher benefits of voting. So they may choose to influence long-term business decision-making, such as R \& D investment strategy. Baysinger (1989) found that corporate R \& D investment is positively related to the proportion of institutional investors, and institutional investors can promote the realization of long-term business strategies and goals. Black (1992) pointed out that institutional investors are more capable of obtaining more comprehensive market information than individual investors in corporate decision-making. With much more objective and accurate judgments, they are motivated to evaluate the long-term benefits of $\mathrm{R} \& \mathrm{D}$ projects and future market prospects. They can affect management decision-making to strengthen $\mathrm{R} \& \mathrm{D}$ investment in the company. Based on the high-tech industry, Hansen \& Hill (1991) examined whether institutional investors can improve firm performance by exerting pressure on management to change the company's R\&D investment. The test results show that the relation between institutional investors' shareholdings and corporate R\&D input is significantly positive. Aghion et al. (2009) argued that institutional investors are positively correlated with technology innovations in listed companies because they 
increase the effectiveness of corporate governance. Hoskisson et al. (2002) argued that pension funds are positively correlated with the technological innovation of listed companies because they are more concerned about the long-term benefits. By an empirical study of Korean firms, Suk Bong Choi et al. (2012) found that institutional investors and overseas shareholders have a positive impact on technological innovation of the company.

The passive view of institutional investors is based on 'shortsightedness' theory. The view states that institutional investors face the pressure of performance evaluation. In order to enhance their investment performance, institutional investors tend to be opportunists with obvious speculation, such as using inertial trading strategies to gain the spread and over-emphasis on short-term goals. The payback period of R \& D investment is long and uncertain. Therefore, institutional investors will force management to cut down long-term capital expenditures such as R \& D to carry out earning management, which will have a negative impact on the $\mathrm{R} \& \mathrm{D}$ investment activities of enterprises.Falkenstein (1996) pointed out in his research that professional fund managers with informational advantages often optimize their portfolios by finding the right investment opportunities in the capital markets. Once the performance of the invested firms declines, the fund managers adjust their holding positions that negatively impact a firm's highrisk and long-term R \&D projects. Froot, Perold \& Stein (1992) argued that due to information asymmetry, institutional investors cannot effectively monitor or assess the quality and effectiveness of $\mathrm{R} \& \mathrm{D}$ expenditures. To a certain extent, information asymmetry exacerbates the responses sensitivity of institutional investors' transactions to corporate earnings. Samuel (1996) studied data from 557 manufacturing firms in the United States between 1985 and 1990, and found that institutional investors' shareholdings can boost their capital expenditure but had a significant negative impact on their $R \& D$ spending and advertising expenditures.

Institutional investors have long been one of the major research areas for corporate governance. The research on the relationship between institutional investors and $\mathrm{R} \& \mathrm{D}$ investment started relatively earlier in western countries. But Chinese domestic research on this issue is still in a stage of gradual development. Whether foreign research results fit our national conditions still needs our further exploration. On the whole, these research results provide some guidance for the theoretical basis and empirical research. Chinese domestic research mainly focuses on institutional investors' influence on corporate management compensation, corporate earnings management, corporate performance and dividend policy and so on. Although there is much academic research on the impact of institutional investors on corporate governance, the research literature on technological innovation in enterprises is still relatively few, and the agreed research results and opinions have not 
been reached yet. This paper studies the influence of institutional investors on enterprises' technical innovation, which caters for the current theme of innovation, and presents a relatively new idea. Through empirical analysis and research on the impact of institutional investors on the $\mathrm{R} \& \mathrm{D}$ investment of listed companies, this study can enrich the theory of corporate external governance, and to some extent make recommendations about how to choose the institutional investors to effectively participate in corporate governance and promote the listed companies Technical innovation to.

\section{Hypothesis development}

Science and technology are the foundation of countries' strength and innovation is the soul of national progress. Faced with increasingly fierce competition, technological innovation is also crucial to the survival and development of enterprises. Research has shown many factors impact the intensity and progress of technological innovation, such as management decision-making, investors' expectations of corporate future development, the length of the investor's shareholding period, and the amount of information that investors hold about the company's R\& D activities.

Enterprise technology innovation is a special investment behavior. In the enterprise hierarchy the decision-making and executive executives have the discretion to decide whether or not to make long-term large investments in developing new technologies. However, the result of R \& D and innovation activities is uncertain and lagging. R\&D activities of enterprises may show effects after many years of substantial continuing investment, and some may even be futile. Such uncertainties of R\&D investment may conflict with management's interests. Corporate management is under pressure to improve business performance, and often manage their earnings by cutting $R \& D$ investment even technology development project is helpful to the future development of the company. Myers (1984) also pointed out that disclosing information about $\mathrm{R} \& \mathrm{D}$ activities can put companies at a disadvantage in the competition. As a result, many corporate management are reluctant to voluntarily disclose relevant information, making it difficult for many small investors to oversee the management decision-making process .It is more difficult to gain a deeper understanding of the true value of enterprise technology innovation and long-term development potential. This nature of technological innovation activities will widen the information gap between investors and corporate management, and influence investors' expectations of the future development of the enterprise, and the duration length of their shareholding period. Thus it further forces corporate management with greater pressure to focus on short-term decision-making.

Institutional investors who bring together small and medium-sized investors are professionals with an absolute advantage in terms of size, 
professionalism and information. First, the close relationship between institutional investors and corporate management shortens the information gap between investors and management, and eliminates the problem of information asymmetry. Because their more real and effective information, institutional investors can objectively monitor and evaluate effectiveness of business management decisions. Second, institutional investors are equipped with professional knowledge of financial theory and rich experience in market operations. They also receive more information when analyzing open market information than ordinary investors. Furthermore, the large holdings and share concentration of institutional investors can enhance the institutional investors' voice in corporate affairs. With relatively larger shareholdings, institutional investors face greater liquidity risk, not free to exit though they have larger share of residual claims.

Relative to individual investors, institutional investors with these advantages are rational. They can have a more objective understanding of corporate technological innovation activities. And they also have their own accurate analysis and judgment on decision-making of technological innovation and corporate value. To some extent, the problem of information asymmetry has been eliminated, and the tendency of corporate management with performance pressure to adopt short-sighted management decision has been reduced. Individual investors' free-riding behavior has been overcome. In addition, the large-scale investment holding of institutional investors makes them to have incentives to strengthen the supervision of operation and management.

To sum up, compared with individual investors, institutional investors have the advantage of promoting technological innovation and corporate R\&D investment decisions. Through effectively curbing short-sighted behavior of corporate management, institutional investors ensure corporate management use Long-term investment funds for enterprises' technological innovation. Based on above analyses, we put forward the main research hypotheses.

H1: The proportion of shares held by institutional investors is positively correlated with corporate $R \& D$ expenditure for technological innovation.

H1-1b: The shareholding of institutional investors also has a positive effect on the increment investment change in $R \& D$ expenditure for technological innovation.

\section{Research design}

4.1 Sample selection and data sources

This study refers to classification index of high-tech industries announced by China Securities Regulatory Commission and National Bureau of Statistics of China. The selected sample of the research was located in 
Shanghai and Shenzhen A shares from 2009 to 2014. Sample companies mainly focus on three industries of manufacturing, scientific research and technology services and information transmission, software and technology services business. These sample companies have a high degree of innovation with $R \& D$ expenditure disclosed in detail. In accordance with the above data processing standards for processing, we finally get 1,728 sample companies. Sample selection and relevant financial data and corporate governance structure data are derived from the WIND database and the CSMAR database. We use SPSS statistical software to analyze all data available.

\subsection{Variables definition}

Based on existing research literature, we use the indicator of $R \& D$ intensity to measure business innovation. There are generally three metrics for this indicator. These include $R \& D$ investment/sales revenue, $R \& D$ investment/total assets, and R\&D investment/ market value, all of which eliminate the differential impact of firm size. In this study, R\&D investment/total assets are used as dependent variables, and $R \& D$ investment/sales revenue is selected as a surrogate variable in the robustness test. Two dependent variables RDI and $\triangle \mathrm{RDI}$, are set, which respectively represent the intensity and increment of annual $R \& D$ expenditure.

Explanatory variable is the shareholding ratio of institutional investors, denoted by INST. Institutional investors in this study include: social security funds, securities investment funds, QFII, securities firms, insurance companies, trust companies, financial companies, enterprise annuity. This variable INST is the sum of the shareholdings of all these institutions in a listed company. We also consider the difference in corporate characteristics. These control variables include SIZE, LEV, GROWTH,AGE, SHARE, and MANAGESH. The definition of these variables is indicated in table 1

Table 1 Variables Definition

\begin{tabular}{|l|l|l|}
\hline Variable Classification & Variable Code & Variable Definition \\
\hline R\&D Intensity & RDI & Annual R \& D Expenditure / Total Assets \\
\hline R\&D Intensity & $\Delta$ RDI & $\begin{array}{l}\text { (R\&D expenditure of the year- R \& D } \\
\text { expenditure of the previous year)/Total assets of } \\
\text { the year }\end{array}$ \\
\hline $\begin{array}{l}\text { Institutional investor ownership } \\
\text { ratio }\end{array}$ & INST & $\begin{array}{l}\text { Institutional investment holdings / Total number } \\
\text { of shares of the company }\end{array}$ \\
\hline Shareholding Concentration & SHARE & $\begin{array}{l}\text { Shareholding number of the largest shareholder } \\
\text { /total number of shares }\end{array}$ \\
\hline Executive Shareholding & MANSH & $\begin{array}{l}\text { Share number of Executives' shareholding / } \\
\text { total number of shares }\end{array}$ \\
\hline Net operating cash flows & OCF & $\begin{array}{l}\text { Net cash flows from operating activities / total } \\
\text { assets }\end{array}$ \\
\hline Enterprise Growth & GROWTH & $\begin{array}{l}\text { (Operating Income for the Year - Operating } \\
\text { Income for the Previous Year) / Operating }\end{array}$ \\
\hline
\end{tabular}




\begin{tabular}{|l|l|l|}
\hline Enterprise Size & SIZE & In (Total Assets) \\
\hline Debt ratio & LEV & Total debt / total assets \\
\hline Year of listing of the enterprise & AGE & $\begin{array}{l}\text { The natural logarithm of the number of years } \\
\text { listed }\end{array}$ \\
\hline Industry Variable & INDU & control \\
\hline Year Variable & YEAR & control \\
\hline
\end{tabular}

\subsection{Research model}

In this study, to a certain extent to avoid endogenous problems, a lagged period of data is used to construct the model. In the study of the impact of institutional investors on the technological innovation of enterprises, this article also fully considered other factors that affect the innovation of enterprises. To test whether the overall ownership of institutional investors has a significant impact on technological innovation in enterprises, two regression models are established to verify the hypothesis.

RDIi, $=\alpha+\beta 1$ INSTi,t- $1+\beta 2$ SHAREi,t-1+ $\beta 3$ MANSHi,t-1+ $\beta 4$ OCFi,t$1+\beta 5$ SIZEi,t-1+ $\beta 6$ LEVi,t-1+ $\beta 7$ AGEi,t-1+ $\beta 8$ INDU $+\beta 9$ YEAR $+\varepsilon$

$\Delta$ RDIi, $=\alpha+\beta 1$ INSTi,t-1+ $\beta 2$ SHAREi,t-1+ $\beta 3$ MANSHi,t- $1+\beta 4$ OCFi,t$1+\beta 5$ SIZEi,t-1+ $\beta 6$ LEVi,t-1+ $\beta 7$ AGEi,t-1+ $\beta 8$ INDU $+\beta 9$ YEAR $+\varepsilon$

\section{(2)}

Where $\mathrm{i}$ is the cross-sectional individuals (each listed company), $\mathrm{t}$ is the year, $\alpha$ is the intercept, $\beta \mathrm{i}(\mathrm{i}=1,2, \ldots)$ is the model regression coefficient, $\varepsilon$ is the random disturbance term.

\section{Empirical results}

\subsection{Descriptive analyses}

Table 2 Descriptive statistics of Institutional shareholding and R\&D expenditure

\begin{tabular}{|l|l|l|l|l|l|}
\hline Variable & Year & Mean & Min & Max & Deviation \\
\hline \multirow{5}{*}{ RDI } & 2009 & 0.0241 & 0.0002 & 0.2119 & 0.0278 \\
\cline { 2 - 6 } & 2010 & 0.0237 & 0.0002 & 0.2097 & 0.0261 \\
\cline { 2 - 6 } & 2011 & 0.0268 & 0.0002 & 0.1959 & 0.0271 \\
\cline { 2 - 6 } & 2012 & 0.0384 & 0.0002 & 0.2456 & 0.0345 \\
\cline { 2 - 6 } & 2013 & 0.0414 & 0.0002 & 0.2422 & 0.0353 \\
\cline { 2 - 6 } & 2014 & 0.0436 & 0.0002 & 0.2486 & 0.0379 \\
\hline \multirow{5}{*}{ INST } & 2008 & 0.3857 & 0.0036 & 0.5255 & 0.2280 \\
\cline { 2 - 6 } & 2009 & 0.4076 & 0.0034 & 0.6925 & 0.2226 \\
\cline { 2 - 6 } & 2010 & 0.4133 & 0.0041 & 0.7233 & 0.2176 \\
\cline { 2 - 6 } & 2011 & 0.4047 & 0.0038 & 0.6793 & 0.2285 \\
\cline { 2 - 6 } & 2012 & 0.4053 & 0.0036 & 0.7229 & 0.2341 \\
\cline { 2 - 6 } & 2013 & 0.4207 & 0.0037 & 0.7677 & 0.2226 \\
\hline
\end{tabular}


Table 3 Descriptive statistics of control variables

\begin{tabular}{|l|l|l|l|l|}
\hline Variable & Mean & Min & Max & Deviation \\
\hline SHARE & 0.3425 & 0.1344 & 0.7156 & 0.09 \\
\hline MANSH & 0.1283 & 0.1978 & 0.6871 & 0.00 \\
\hline OCF & 0.0447 & 0.0629 & 0.2338 & -0.1445 \\
\hline GROWTH & 0.1575 & 0.2210 & 1.7316 & -0.2333 \\
\hline SIZE & 21.6926 & 1.0069 & 25.015 & 19.6985 \\
\hline LEV & 0.4142 & 0.1957 & 0.8953 & 0.0466 \\
\hline AGE & 1.8540 & 0.7437 & 3.0445 & 0.6931 \\
\hline
\end{tabular}

As shown in Table 2, the average share of institutional investors in $2008-2013$ is $38.57 \%, 40.76 \%, 41.33 \%, 40.47 \%, 40.53 \%$ and $42.07 \%$ respectively. Generally speaking, it is a gradual increase trend, especially in 2013, a larger increase. This shows that institutional investors are gradually becoming an important force in China's capital market, but there is a big gap between the institutional investors in different companies. The RDI, R\&D expenditure of technological innovation has also shown a clear upward trend. It can be seen that the shareholding ratio of institutional investors is consistent with the overall trend of changes in input indicators of technological innovation. However, there are still relatively more differences in technological innovations among different enterprises. Under normal circumstances, the $\mathrm{R} \& \mathrm{D}$ expenditure intensity of enterprises needs to reach $2 \%$ in order to survive, reaching more than $5 \%$ to be competitive, so the $\mathrm{R} \&$ $\mathrm{D}$ investment of listed companies in China still need to be strengthened. In general, most enterprises are growing fast, which is related to the sample selection of enterprises with high technology content. It shows that the difference of ownership concentration between enterprises is relatively large, and the degree of incentive mechanism of management shareholding among different listed companies is different.

\subsection{Correlation analyses}

In order to make the model more scientific, before the regression, we use the Pearson correlation coefficient test method to test the correlation between the variables. If the correlation coefficient between the variables is small, then the correlation degree between the variables is not very large. There is no serious multicollinearity problem between variables. From table 4 , we can clearly see that all the correlation coefficients between variable are less than 0.5, which is within the acceptable range. Therefore, although we choose more control variables, there is no significant multicollinearity between the explanatory variables and the control variables. 
Table 4 Pearson correlation coefficient between explanatory variables and control variables

\begin{tabular}{|c|c|c|c|c|c|c|c|c|}
\hline & INST & MANSH & SHARE & GROWTH & $\mathrm{OCF}$ & SIZE & LEV & AGE \\
\hline INST & 1 & & & & & & & \\
\hline MANSH & $\overline{0} .4813$ & 1 & & & & & & \\
\hline SHARE & 0.3418 & -0.1013 & 1 & & & & & \\
\hline GROWTH & 0.0078 & 0.0078 & 0.0134 & 1 & & & & \\
\hline $\mathrm{OCF}$ & 0.1488 & -0.0139 & 0.0708 & -0.0031 & 1 & & & \\
\hline SIZE & 0.3521 & 0.2927 & 0.2152 & 0.0269 & 0.0729 & 1 & & \\
\hline LEV & 0.0348 & -0.1219 & -0.0086 & 0.004 & $\overline{-}-0664$ & 0.0852 & 1 & \\
\hline AGE & 0.2684 & 0.3047 & -0.0629 & 0.0227 & 0.0067 & 0.3925 & 0.1555 & 1 \\
\hline
\end{tabular}

\subsection{Regression results}

Because of some endogenous problems between institutional investors and enterprise technology innovation, this study selected a lagged period of data for testing. Taking into account the existence of heteroskedasticity with mixed cross-sectional data, regression analyses use White Gaussian variance covariance matrix to revise the regression equation. Regression results of institutional shareholding on R\&D expenditure intensity are shown in Table 5. From table 5, we can see that the RDI regression model has a R2 of 0.1495 ( $F$ value of 82.67 ), and the $\triangle \mathrm{RDI}$ regression model has a R2of 0.0121 with $\mathrm{F}$ value of 5.18. The reason is that there are many factors that affect technological innovation of enterprises. The explanatory and control variables selected by the article cannot include all the influencing factors.

The regression results indicate coefficients of all variables are significant, and the sign of coefficient estimates are basically in line with the realistic economic expectation. It shows that the model can give a more scientific explanation for the impact of institutional investors on technological innovation of enterprises. From Table 5, we can see that the overall shareholding ratio of institutional investors, INST, is positively correlated to R\&D expenditure, RDI and $\triangle \mathrm{RDI}$ at significant level 1\%. These empirical results indicate that the higher the proportion of institutional investors' shareholding, the more R\&D and incremental R\&D expenditure invested by enterprises. To some extent, it show institutional investors can better promote corporate investment in technological innovation. These research results support hypothesis 1 and hypothesis 2 . This conclusion is also consistent with the many scholars' studies in line with the market rules that institutional ownership can improve corporate governance. At the same time, the conclusion of the study is of great significance to the vigorous development of institutional investors in China and provides a practical basis for Chinese government to formulate policies to encourage institutional investors to participate in technological innovation of enterprises. 
Table 5 Institutional investor ownership of R \& D intensity of the regression results

\begin{tabular}{lcc}
\hline \multirow{2}{*}{ Coefficient } & RDI (OLS) & $\Delta$ RDI (OLS) \\
& Model 1 & Model 2 \\
\hline \multirow{2}{*}{ Intercept } & $0.1261^{* * *}$ & 0.0042 \\
& $(12.39)$ & $(0.58)$ \\
INST & $0.0112^{* * *}$ & $0.0060^{* * *}$ \\
& $(4.64)$ & $(3.00)$ \\
MANSH & $0.0272^{* * *}$ & $0.0086^{* * *}$ \\
& $(7.83)$ & $(3.13)$ \\
SHARE & $-0.0185^{* * *}$ & $-0.0050^{*}$ \\
& $(-5.05)$ & $(-1.79)$ \\
GROWTH & $0.0137 * * *$ & $0.0032^{*}$ \\
& $(3.12)$ & $(1.78)$ \\
OCF & 0.0075 & $0.0117^{* *}$ \\
& $(0.99)$ & $(2.12)$ \\
SIZE & $-0.0034 * * *$ & -0.0003 \\
& $(-6.94)$ & $(-0.78)$ \\
LEV & $-0.0052^{* *}$ & $-0.0063^{* * *}$ \\
& $(-2.39)$ & $(-3.82)$ \\
AGE & $-0.0090^{* * *}$ & $0.0020^{* * *}$ \\
YEAR & $(-10.68)$ & $(2.90)$ \\
INDUS & Control & Control \\
F-statistic & Control & Control \\
R2 & $82.67 * * *$ & $5.18^{* * *}$ \\
$\mathrm{~N}$ & 0.1495 & 0.0121 \\
***significant at the $1 \%$ & 4006 \\
& 4006 & level **significant at the $5 \%$ \\
& & level $*$ significant at the 10\% level
\end{tabular}

In addition, MANSH is highly positively correlated with the intensity of $\mathrm{R} \& \mathrm{D}$ investment at $1 \%$ significant level. It indicates that senior management ownership makes corporate management have sufficient incentive to participate in promoting technological innovation of enterprises, which effectively reduce agency problem in corporate operation. From this, management shareholding incentives encourage increase in R\&D investment, which is beneficial to the enhancement of corporate long-term value. Variable SHARE is highly negatively correlated with R\&D investment at $1 \%$ significant level. It indicate that the higher the proportion of large shareholders, the more motivation for them to occupy private interests by invading corporate long-term interests.

Thus abuse behaviors of majority shareholders reduce corporate $R \& D$ investment and weaken technological innovation. Variable GROWTH is highly positively correlated to $R \& D$ intensity, indicating that the higher the growth of enterprises, the more motivation to increase $R \& D$ investment to maintain its core competitiveness in order to expand market share. There is a significant negative correlation between the debt ratio (LEV) and 
technological innovation behavior of enterprises, which indicates that the greater the financial risk, the lower the willingness of technological innovation. To some extent, for highly leveraged companies cash flows are strictly constrained, which hinder the improvement of technological innovation. Net cash flow from business activities (OCF), though not significant, also positively influenced the expenditure in technological innovation.

\subsection{Robustness test}

In order to verify the correctness of the conclusion, this study also have robustnesee test to examine the relationship between institutional investors' shareholding and technological innovation behavior of enterprises. In robust test we use the method of substituting variables and downsizing samples respectively from two aspects. We standardize $R \& D$ investment and replace explanatory variable with RDR, which is R\&D expenditure divided by total sales. We also have some sub-sample tests. All hypothetical models of this study are validated to prevent the conclusions of the study from being biased due to objective reasons. For all variables, including the control variables, the sign of the estimates are consistent with the regression analysis, indicating that the research on enterprise innovation investment has a certain scientific and stability.

\section{Conclusion}

Based on theoretical basis of institutional investors' participation in corporate governance, this study explores the relationship between institutional investors and corporate innovation in the academic field. This study analyzes the mechanism of institutional investors' impact on corporate technological innovation. We found that institutional investor ownership is positively correlated with corporate total and incremental R\&D investment. As a result, The participation of institutional investors positively impact enterprise Technology Innovation. We have reason to believe that increasing the proportion of institutional investors 'shareholdings can effectively promote and encourage innovative improvement of enterprises. It further provides the impetus for healthy development of Chinese capital market, and promotes the transformation and upgrading of Chinese economy. The research results of this paper can play an enlightening role in the improvement of corporate governance mechanism and the development of institutional investors. The result shows that institutional investors in the Chinese market generally promote technological innovation behavior of enterprises. Therefore, this study proposes that Chinese regulators continue to cultivate and develop institutional investors. Effective participation mechanism from institutional investors would enhance the core competitiveness of enterprises 
and achieve the goal of improving corporate performance. As a result, we should motivate institutional investors actively participate in supervising technological innovation activities in enterprises.

\section{References:}

1. Holderness, C. lifford, G, Dennis, P. Sheehan. The role of majority shareholders in publicly held corporations: An exploratory analysis, The Journal of Finance, 1988, pp.78 89

2. Baysinger, R. D., R. E. Hoskisson,. Diversification strategy and R\&D intensity in multiproduct firms, The Academy of Management Journal , 1989 , pp:45 50

3. Black, B. S. Agents Watching Agents: the Promise of Institutional Investor Voice,UCLA Law Review, No.39, 1992, pp:811 893

4. Hansen, G., Hill, C. Are Institutional Investors Myopic? A Time-series Study of Four Technology-driven Industries, Strategic Management Journal, No.6,1991, pp:1 16

5. Hoskisson, R. E., Hitt, M. A., Johnson, R. A., Grossman, W., Conflicting Voices: The effects of institutional ownership heterogeneity and internal governance on corporate strategies, Academy of Management Journal, No.45, 2002, pp: 697 716

6. Suk Bong Chio, Byung II Park, Paul Hong. Does Ownership Structure Matter for Firm technological Innovation Performance? The case of Korean Firms, Corporate Governance: An International Review, No.20, Vol.3, 2012, pp:267 288

7. E G Falkenstein. Preferences for Stock Characteristics as Revealed by Mutual Fund Portfolio Holdings, Journal of Finance, No.1, 1996, pp: $111 \sim 135$

8. Samuel, C. Stock Market and Investment: The Governance Role of the Market, World Bank Working Paper, 1996

9. Myers, S., The Capital Structure Puzzle[J], Journal of Finance, No.39,1984, pp.575 592 